\section{Emerging horizons of salivary diagnostics for periodontal disease}

\author{
L. Fuentes, ${ }^{1}$ M. Yakob ${ }^{1}$ and D. T. W. Wong ${ }^{* 1}$
}
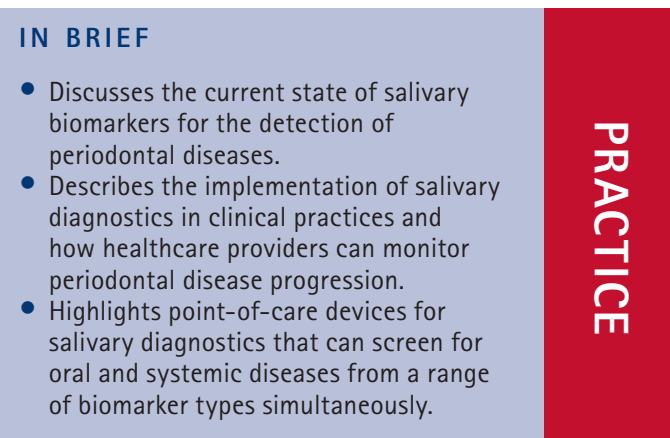

The field of salivary diagnostics to allow risk determination for periodontal diseases is advancing. New technologies in proteomics, genomics and nanotechnologies have continued the discovery of discriminatory periodontal disease biomarkers. This review briefly overviews biomarker studies that have been completed in saliva for the detection of periodontal disease since 2010. Disease specific biomarkers could be used in risk determination, treatment planning and disease progression. Currently, diagnostic tests are commercially available, and the development of point-of-care tests is expanding. Even though challenges remain, salivary diagnostics for periodontal disease is promising and could facilitate the diagnostics and treatment in a clinical practice by dental practitioners.

\section{INTRODUCTION}

Periodontal diseases refer to inflammation of the gingival tissue surrounding the teeth and the supportive structures of teeth that are highly prevalent. ${ }^{1-3}$ Inflammation of the gingival tissue (gingivitis) arises when dental plaque accumulates along the gingival margin due to poor oral hygiene. ${ }^{4,5}$ If not treated, gingivitis can progress to periodontitis, which is distinguished by destruction of supporting connective tissue, alveolar bone loss, and ultimately result in tooth loss. ${ }^{6}$ Periodontitis is a multifactorial disease with complex pathogenesis. Although microorganisms are the main etiological agents, genetic predisposition and environmental factors, such as smoking, can alter the host immune-inflammatory response. ${ }^{7-18}$ Gingivitis is common in the United States with reports indicating upwards of 50\% of the adult population had gingivitis..$^{19,20}$ A survey of adults in the United Kingdom estimated that $42 \%$ of 35-44 years old and $70 \%$ of 55-64 years showed evidence of periodontitis, ${ }^{21}$ and similar results were found in American adults. ${ }^{22}$

Treatment of plaque-induced periodontal disease begins with controlling the biofilm by

Centre for Oral/Head \& Neck Oncology Research, University of California, Los Angeles, 73017 CHS, 10833 Le Conte Avenue, Los Angeles, CA 90095, USA. ${ }^{*}$ Correspondence to: David T. W. Wong

Tel: +1 310206 3048; Fax: +1 3108257609 Email:dtww@ucla.edu

\section{Refereed Paper}

Accepted 22 July 2014

DOI: 10.1038/sj.bdj.2014.1005

${ }^{\circledR}$ British Dental Journal 2014; 214: 567-573 professional oral hygiene cleaning, scaling, and root planning, along with oral hygiene instructions. ${ }^{23-26}$ In cases where controlling the plaque is not sufficient or in aggressive disease form, the treatment options include the use of systemic antibiotics or periodontal surgery to gain further access to the root for debridement, alongside procedures to regenerate lost tissues. ${ }^{27-31}$ Successful treatment for periodontitis may reduce inflammation and regenerate some of the supporting bone and connective tissues. While gingivitis is preventable and reversible with proper oral hygiene, periodontitis is an irreversible condition since a complete restoration of the lost tooth and support is impossible. ${ }^{9}$

Common symptoms for periodontitis are spontaneous bleeding, loosening of teeth, sporadic pain and discomfort. However, both patients and dental practitioners underestimate the disease since it can be painless and asymptomatic, and thus go unnoticed and untreated for years. Noting that the bone loss associated with periodontitis is irreversible makes it imperative for oral health providers to identify periodontal disease progression as soon as possible to minimise adverse health effects. Currently, progression of periodontal disease from gingivitis to periodontitis is not well described, as clinicians often use criteria that rely on measurements that are error-prone and classifications that require the knowledge of the rate of disease progression where this may be unavailable. ${ }^{32-35}$ Despite the advancements made in the pathogenesis of periodontal disease, most diagnoses are still based almost entirely in traditional clinical assessment criteria that include presence or absence of bleeding upon probing (BOP), probe pocket depth, ${ }^{32}$ clinical attachment loss (CAL), and the patient's medical and dental histories. ${ }^{36,37}$ However, this visual method of evaluating periodontal disease may only state the presence or absence of periodontal disease. It leaves no opportunity for the ability to predict future diseases, to determine the underlying cause of a present disease, or to determine the appropriate treatment plan for each individual. With the growing use of genomics, proteomics, and bioinformatics in medicine, noninvasive methods for disease diagnosis are attractive endeavours.

The field of salivary diagnostics to allow risk determination for both oral and systemic diseases is advancing. Researchers are looking into the use of saliva as a diagnostic medium that would be able to aid clinicians in risk determination, diagnosis, and treatment planning for periodontal diseases. ${ }^{38-43}$

\section{SALIVA AS A DIAGNOSTIC MEDIUM}

Saliva is a promising target for diagnostic tests as its collection is noninvasive and it is readily available. Biomarkers for the detection of diseases, such as caries, oral cancer and periodontal disease, as well as systemic disease such as hepatitis, Sjögren's syndrome, breast cancer, pancreatic cancer and HIV have been shown to be present in saliva. ${ }^{44-51}$ Whole saliva can be obtained by either unstimulated or stimulated collection. Stimulated saliva collection is accomplished by masticatory or gustatory stimulation, for example, chewing on parafifin or 
placing citric acid on the patient's tongue. Unstimulated saliva collection occurs when there is no masticatory, gustatory, or mechanical stimulation and is mainly affected by patient hydration level..$^{52}$ Whole saliva contains a mixture of fluids from the major and minor salivary glands, gingival crevicular fluid (GCF), serum, immune and epithelial cells, and many microbes. ${ }^{53} \mathrm{~A}$ large body of scientific research has focused on GCF biomarkers that communicate sitespecific periodontal disease progression; however, it is more difficult to implement clinically due to the possibility for salivary contamination, difficulty to probe all tooth sites and potentially statistical method error. ${ }^{54-58}$ Therefore, this review will focus on advances in salivary biomarkers for periodontal disease, as all components of whole saliva are analysed without risking local fluid contamination.

\section{CURRENT DETECTED BIOMARKERS FOR PERIODONTAL DISEASE}

A wide variety of classes of biomarkers are found in saliva including proteins of host and bacterial origin; DNA and mRNA of host, bacterial, and viral origin; ions and steroid hormones. ${ }^{59-61}$ Papers since 2010 have shown that microbial, genetic damage and protein biomarkers obtained from saliva are informative in the detection of gingival inflammation and periodontal disease activity (see Table 1). These recent studies add to an already existing wealth of research that has shown and confirmed detectable biomarkers for periodontal disease in saliva. For many biomarker studies the area under the receiver operating characteristics (ROC) curve (AUC) is an important measurement to report the performance of a biomarker by indicating whether the biomarker can discriminate between individuals with and those without the disease. The measurement ranges from 50\%, representing a test no better than chance, and 100\%, representing a perfect diagnostic test. ${ }^{62,63}$

Matrix metalloproteinases (MMPs) are zinc-dependent proteases that are known to be associated in diseases such as arthritis, atherosclerosis, as well as periodontitis, because they are involved in the degradation of various extracellular, pericellular and nonmatrix substrates. ${ }^{64-66}$ MMPs are regulated by a family of endogenous inhibitors, called the tissue inhibitors of metalloproteinases (TIMP) and the ratio of MMP/TIMP has been a useful measurement to identify potential imbalances between synthesis and degradation as an indicator of periodontal disease. ${ }^{67,68} \mathrm{In}$ particular, MMP-8 has been known to be a biomarker for inflammatory and periodontal diseases. ${ }^{69-71}$ Recent studies further confirmed this association. In a Finnish population, MMP-8 in saliva was tested by two detection methods, immunofluorometric assay (IFMA) and enzyme-linked immunoassay (ELISA), and it was found that detection of periodontitis subjects from controls was stronger by IFMA than ELISA (area under the ROC curve (AUC) reported as 0.751 and 0.592 , respectively). ${ }^{72}$ The study also found that utilising MMP-8 with one other marker, either pyridinoline crosslinked carboxyterminal telopeptide of type I collagen (ICTP) or TIMP-1, increased the AUC for non-smoking groups. The AUC values were reported as 0.819 and 0.817 for the protein combinations in non-smoking subjects. MMP-8 was further researched in a Swedish population and this study confirmed it was able to significantly discriminate severe periodontitis over less advanced periodontitis ( $\mathrm{p}<0.001)$, showing that MMP-8 is also able to function as a marker for periodontal disease activity. ${ }^{73}$ In the same study, interleukin- $1 \beta$ (IL-1 $\beta$ ) and the protein combination ratio of MMP-8/ TIMP-1 was higher in severe periodontitis patients ( $\mathrm{p}<0.001)$.

A study conducted at the University of Kentucky reported that MMP-8 was higher in chronic adult periodontitis patients than healthy controls (AUC: 0.92). ${ }^{74}$ The study also showed this same high detection capabilities in IL-1 $\beta$ and interleukin-6 (IL-6) (AUC: 0.95 for both) and when these three protein markers were combined the AUC elevated to 0.984 with a sensitivity of 0.94 and specificity of 0.966 . MMP-9, previously shown to increase with periodontal disease severity, ${ }^{75}$ and TIMP-1 was studied in a Colombian population. Significantly higher levels of both MMP-9 and TIMP-1 were seen in chronic periodontitis subjects compared with healthy controls ( $p$ values were $<0.001$ and 0.010 , respectively) and when used in combination, significance was also shown between the two groups $(\mathrm{p}<0.001){ }^{76}$

Other protein biomarkers in saliva for periodontal disease have recently been studied. Quantitative proteomics was analysed to determine the alterations in the salivary proteome before and after periodontal treatment was administered. ${ }^{77}$ The prominent findings were for proteins S100A6, S100A8, and S100A9 where abundance increased by fold changes of 1.64, 2.31, and 1.99, respectively. Levels of S100A8/A9 have previously been shown in GCF and saliva to correlate with periodontitis likely due to active secretion by gingival keratinocytes and neutrophils that are infiltrating. ${ }^{78,79}$ However, S100A6 has little reports associating the protein to inflammation. One study showed an upregulation of S100A6 in a mouse model of asthma. ${ }^{80}$ Noting that the S100 proteins increased in abundance during the disease inactive state highlights the involvement in the host response during periodontitis. These may be potential biomarkers for monitoring periodontal disease activity. Macrophage inflammatory protein-1a (MIP-1a), an upstream signalling molecule associated with bone resorption by osteoclasts, was recently studied at the University of Kentucky. ${ }^{81}$ Results found that MIP- $1 \alpha$ can significantly detect periodontal disease from controls (AUC: 0.94). Lactoferrin, a metalloprotein found in exocrine secretions that has previously shown correlations with chronic periodontitis in $\mathrm{GCF},{ }^{82}$ was also investigated in a Swedish study. ${ }^{83}$ The study showed an association between chronic periodontitis patients and increased lactoferrin concentration compared with healthy controls in saliva $(\mathrm{p}<0.05)$.

Markers of DNA damage that are excreted in bodily fluids can also be useful in diagnostics as they are evident of active DNA repair. ${ }^{84}$

8-Hydroxydeoxyguanosine $(8-\mathrm{OHdG})$ is an oxidized nucleoside that is commonly used as a marker for oxidative DNA damage in inflammatory diseases. ${ }^{85-87} 8-0 \mathrm{HdG}$ was further studied in saliva to determine its potential as a marker for periodontitis disease activity in a Turkish population. Results found that 8-0HdG levels of the chronic periodontitis group were statistically higher than healthy and chronic gingivitis subjects ( $p<0.001)$. This may be useful as a marker for periodontal disease activity as it is also correlated with PD and CAL $(p<0.001)$ that are used as disease severity parameters. ${ }^{88}$

Bacteria in saliva have also been recently confirmed to be biomarkers for periodontitis. Previous studies have shown the relationship between salivary microorganisms and periodontal disease. ${ }^{7,89} \mathrm{~A}$ recent study aimed to determine if microbe salivary copy-count could be utilised to distinguish between individuals of different periodontal health classifications. The results showed that three bacterial species, Porphyromonas gingivalis, Tannerella forsythia and Prevotella intermedia, could identify periodontitis groups from healthy and gingivitis subjects with high sensitivity and specificity solely on their salivary copy-counts by Taq-man real-time PCR. This data suggests that using saliva microbial copy-counts may be useful in a clinical setting to determine individuals with periodontitis; however, more studies need to be conducted to be able to distinguish the different subtypes of periodontitis. ${ }^{90}$

Currently, there is no single biomarker that is specific to identify periodontal disease. 
Table 1 The results of tested biomarkers for periodontal disease and the clinical parameters used in some recent publications. In addition to p-value, area under curve (AUC) values are presented when provided

\begin{tabular}{|c|c|c|c|c|c|}
\hline Biomarkers & Class & Result & Method & $\begin{array}{l}\text { Clinical parameters and } \\
\text { sample size }\end{array}$ & Reference \\
\hline $\begin{array}{l}\text { Matrix metalloproteinase-8 } \\
\text { (MMP-8) }\end{array}$ & Protein & $\begin{array}{l}\text { MMP-8 differentiation between } \\
\text { periodontitis and control subject, IFMA } \\
\text { showed AUC: } 0.751(p<0.001) \text { and ELISA } \\
\text { showed AUC: } 0.592(p=0.044) \text {. }\end{array}$ & \multirow[t]{3}{*}{$\begin{array}{l}\text { Immunofluorometric } \\
\text { assay (IFMA) and } \\
\text { Enzyme-linked } \\
\text { immunoassay } \\
\text { (ELISA) }\end{array}$} & \multirow[t]{3}{*}{$\begin{array}{l}\text { Advanced periodontitis group with } \\
\text { at least } 14 \text { teeth with PPD } \geq 4 \mathrm{~mm} \\
\text { pocket depths and BOP }(n=84) \text {. } \\
\text { Control group that had no teeth } \\
\text { with PPD } \geq 4 \mathrm{~mm}(n=81) \text {. }\end{array}$} & \multirow[t]{3}{*}{69} \\
\hline $\begin{array}{l}\text { MMP-8 and pyridinoline } \\
\text { cross-linked carboxyterminal } \\
\text { telopeptide of type I } \\
\text { collagen (ICTP) combination }\end{array}$ & $\begin{array}{l}\text { Protein } \\
\text { Combination }\end{array}$ & $\begin{array}{l}\text { The combination of MMP-8 and ICTP } \\
\text { differentiated periodontitis and control } \\
\text { in smoker and non-smoker groups (AUC: } \\
0.674 \text { and } 0.819 \text {, respectively). }\end{array}$ & & & \\
\hline $\begin{array}{l}\text { MMP-8/Tissue inhibitor of } \\
\text { matrix metalloproteinase- } 1 \\
\text { (TIMP-1) Ratio }\end{array}$ & $\begin{array}{l}\text { Protein } \\
\text { Combination }\end{array}$ & $\begin{array}{l}\text { The ratio of MMP-8 over TIMP-1 was able } \\
\text { to differentiate periodontitis and control } \\
\text { in smoker and non-smoker groups (AUC: } \\
0.698 \text { and } 0.817 \text {, respectively). }\end{array}$ & & & \\
\hline MMP-8 & Protein & $\begin{array}{l}\text { Subjects with severe periodontitis } \\
\text { showed significantly higher MMP- } 8 \\
\text { concentrations than the other } 2 \text { groups } \\
(p<0.001) \text {. }\end{array}$ & \multirow[t]{3}{*}{$\begin{array}{l}\text { IFMA, ELISA and } \\
\text { Luminex }\end{array}$} & \multirow{3}{*}{$\begin{array}{l}\text { Periodontal disease (PD) with } \\
\text { no loss of bone tissue ( } n=303) \text {, } \\
\text { PD with horizontal loss of bone } \\
\text { tissue greater than one-third } \\
\text { of root length in }<30 \% \text { of sites } \\
\text { ( } n=89) \text {, and severe periodontitis } \\
\text { with horizontal bone loss greater } \\
\text { than one-third of the root length } \\
\text { in }>30 \% \text { of the sites }(n=49) \text {. }\end{array}$} & \multirow[t]{3}{*}{70} \\
\hline Interleukin-1 $\beta$ (IL-1 $\beta)$ & Protein & $\begin{array}{l}\text { Subjects with severe periodontitis showed } \\
\text { significantly higher IL- } 1 \beta \text { concentrations } \\
\text { than the other } 2 \text { groups }(p<0.001) \text {. }\end{array}$ & & & \\
\hline MMP-8/TIMP-1 & $\begin{array}{l}\text { Protein } \\
\text { Combination }\end{array}$ & $\begin{array}{l}\text { The MMP-8/TIMP-1 ratio was significantly } \\
\text { higher in severe periodontitis group } \\
(p<0.001) \text {. }\end{array}$ & & & \\
\hline Interleukin-1 $\beta$ (IL-1 $\beta)$ & Protein & $\begin{array}{l}\text { Salivary levels of IL-1 } 1 \beta \text { were significantly } \\
\text { higher in chronic adult periodontitis subjects } \\
\text { compared with healthy (AUC: } 0.95 p<0.0001 \text { ). }\end{array}$ & \multirow[t]{4}{*}{ ELISA and Luminex } & \multirow{4}{*}{$\begin{array}{l}\text { Chronic periodontitis group } \\
\text { included participants that had five } \\
\text { qualifying sites in two quadrants } \\
\text { with each site having PPD } \geq 5 \mathrm{~mm} \text {, } \\
\text { CAL of } \geq 3 \mathrm{~mm} \text {, and BOP score } \\
\text { of } \geq 2 \text { ( } n=50 \text { ). Healthy participants } \\
\text { enrolled had BOP in less than } 10 \% \\
\text { of sites, PPD of } \geq 5 \mathrm{~mm} \text { in }<2 \% \\
\text { of sites, no PPD } \geq 6 \mathrm{~mm} \text {, and CAL } \\
\text { of }>2 \mathrm{~mm} \text { in }<1 \% \text { of sites }(n=30) \text {. }\end{array}$} & \multirow[t]{4}{*}{71} \\
\hline Interleukin-6 (IL-6) & Protein & $\begin{array}{l}\text { Salivary levels of IL- } 6 \text { were significantly } \\
\text { higher in chronic adult periodontitis } \\
\text { subjects compared with healthy (AUC: } \\
0.95 p<0.0001 \text { ). }\end{array}$ & & & \\
\hline MMP-8 & Protein & $\begin{array}{l}\text { Salivary levels of MMP- } 8 \text { were significantly } \\
\text { higher in chronic adult periodontitis subjects } \\
\text { compared with healthy (AUC: } 0.92 p<0.0001 \text { ). }\end{array}$ & & & \\
\hline $\mathrm{IL}-1 \beta+\mathrm{IL}-6+\mathrm{MMP}-8$ & $\begin{array}{l}\text { Protein } \\
\text { Combination }\end{array}$ & $\begin{array}{l}\text { Using the panel of three biomarkers in } \\
\text { combination, IL-1 } \beta+\text { IL-6 + MMP-8 were } \\
\text { able to distinguish periodontitis from health } \\
\text { with high discriminatory capability (AUC: } \\
0.984 \text {; sensitivity: } 0.94 \text {; specificity: } 0.966 \text { ). }\end{array}$ & & & \\
\hline $\begin{array}{l}\text { Matrix metalloproteinase-9 } \\
\text { (MMP-9) }\end{array}$ & Protein & \multirow{3}{*}{$\begin{array}{l}\text { Significantly higher levels of both MMP-9 } \\
\text { and TIMP- } 1 \text { were seen in CP subjects } \\
\text { compared with HC ( } p<0.001 \text { and } 0.010 \\
\text { respectively). When used in combination, } \\
\text { significance was also shown between the } \\
\text { two groups ( } p<0.001 \text { ). }\end{array}$} & \multirow{4}{*}{$\begin{array}{l}\text { ELISA and } \\
\text { Polymerase chain } \\
\text { reaction-restriction } \\
\text { fragment length } \\
\text { polymorphism } \\
\text { (PCR-RFLP) }\end{array}$} & \multirow{4}{*}{$\begin{array}{l}\text { Chronic periodontitis (CP) subjects } \\
\text { had at least four tooth sites with } \\
P D \geq 4 \mathrm{~mm} \text { and CAL } \geq 2 \mathrm{~mm} \text {, and } \\
\text { radiographic evidence of bone loss } \\
\text { of }>2 \mathrm{~mm} \text { ( } n=69 \text { ). Healthy control } \\
\text { (HC) subjects had no sites of } \\
\text { PPD }>3 \mathrm{~mm} \text { and no more that } 10 \% \\
\text { sites BOP }(n=54) \text {. }\end{array}$} & \multirow[t]{4}{*}{73} \\
\hline TIMP-1 & Protein & & & & \\
\hline MMP-9/TIMP-1 Ratio & $\begin{array}{l}\text { Protein } \\
\text { Combination }\end{array}$ & & & & \\
\hline MMP-9-1562C/T & $\begin{array}{l}\text { Gene } \\
\text { Promoter } \\
\text { Polymorphism }\end{array}$ & $\begin{array}{l}\text { Results found that there was no } \\
\text { association between the different MMP-9 } \\
\text { genotypes and chronic periodontitis. Also, } \\
\text { the gene promoter polymorphism was not } \\
\text { associated with different levels of anlyzed } \\
\text { salivary biomarkers ( } p>0.05 \text { ). }\end{array}$ & & & \\
\hline $\begin{array}{l}\text { S100 proteins } \\
(\mathrm{S} 100 \mathrm{~A} 6, \mathrm{~A} 8, \mathrm{~A} 9)\end{array}$ & Protein & $\begin{array}{l}\text { The average fold change of S100A6, } \\
\text { S100A8, and S100A9 between pre- and } \\
\text { post-treatment samples was } 1.64,2.31 \text {, } \\
\text { and } 1.99 \text {, respectively. }\end{array}$ & $\begin{array}{l}\text { 2D sodium } \\
\text { dodecyl sulphate } \\
\text { polyacrylamide gel } \\
\text { (SDS-PAGE) }\end{array}$ & $\begin{array}{l}\text { The criteria for inclusion were } \\
\text { at least two PPD of } \geq 5 \mathrm{~mm} \text {, at } \\
\text { least } 50 \% \text { of teeth showing PPD } \\
\text { of } \geq 3 \mathrm{~mm} \text { and } 10 \% \text { BOP }(\mathrm{n}=9) \text {. } \\
\text { Saliva samples were collected } \\
\text { before and after periodontal } \\
\text { treatment from each individual. }\end{array}$ & 74 \\
\hline
\end{tabular}

Therefore, the discovered salivary biomarkers from microbial and host origins can be used in combination to increase the specificity for diagnosis of current periodontal and future disease progression in a clinical setting. ${ }^{60,91}$ There are two commercially available salivary diagnostic tests for the detection of periodontal diseases. ${ }^{92}$ The first,
MyPerioPath ${ }^{\circledR}$, identifies the species and concentration of salivary bacteria that are associated with gingivitis and periodontitis, thus supporting the clinician to identify future 


\begin{tabular}{|c|c|c|c|c|c|}
\hline \multicolumn{6}{|l|}{ Continued from page 569} \\
\hline $\begin{array}{l}\text { Macrophage inflammatory } \\
\text { protein-1a (MIP-1a) }\end{array}$ & Protein & $\begin{array}{l}\text { Mean values of MIP- } 1 \text { a were significantly } \\
\text { higher in periodontal disease group } \\
\text { than the control group }(p<0.0001) \text {. } \\
\text { In the receiver operator characteristic } \\
\text { (ROC) analyses, this marker had an AUC } \\
\text { of } 0.94 \text {. MIP-1a also demonstrated a } \\
\text { strong positive correlation between } \\
\text { clinical parameter of periodontal disease } \\
(p<0.0001) \text {. }\end{array}$ & $\begin{array}{l}\text { Enzyme } \\
\text { immunosorbent } \\
\text { assays (EIA) }\end{array}$ & $\begin{array}{l}\text { Participants in the periodontal } \\
\text { disease group had to have five sites } \\
\text { in two quadrants with a minimum } \\
\text { of two affected teeth in each } \\
\text { quadrant, each site needed } \geq 5 \mathrm{~mm} \\
\text { PPD, CAL } \geq 3 \mathrm{~mm} \text {, and BOP with } \\
\text { score } \geq 2 \text { ( } n=40 \text { ). The control group } \\
\text { showed no more than } 10 \% \text { of BOP } \\
\text { sites, PPD } \geq 5 \mathrm{~mm} \text { in less than } 2 \% \\
\text { of sites, and clinical attachment } \\
\text { loss }>2 \mathrm{~mm} \text { in }<1 \% \text { of sites }(n=40) \text {. }\end{array}$ & 78 \\
\hline Lactoferrin & Protein & $\begin{array}{l}\text { Subjects with chronic periodontitis } \\
\text { displayed higher concentrations of } \\
\text { lactoferrin compared with periodontally } \\
\text { healthy subjects ( } p<0.05) \text {. The } \\
\text { concentration of salivary lactoferrin was } \\
\text { positively correlated with BOP and number } \\
\text { of sites with PPD } \geq 6 \mathrm{~mm}(p<0.001) \text {. }\end{array}$ & ELISA & $\begin{array}{l}\text { Participants in the test group were } \\
\text { required to show general horizontal } \\
\text { bone destruction of at least one- } \\
\text { quarter of the root length, at least } \\
\text { four teeth with pockets } \geq 5 \mathrm{~mm} \text {, } \\
\text { and to be positive for BOP ( } n=17) \text {. } \\
\text { Control subjects had no bone loss } \\
\text { and no pockets }>4 \mathrm{~mm}(n=17) \text {. }\end{array}$ & 80 \\
\hline $\begin{array}{l}\text { 8-hydroxy-deoxyguanosine } \\
\text { (8-OHdG) }\end{array}$ & $\begin{array}{l}\text { Marker of } \\
\text { oxidative DNA } \\
\text { damage }\end{array}$ & $\begin{array}{l}\text { The mean } 8-0 H d G \text { levels of chronic } \\
\text { periodontitis group was significantly } \\
\text { higher than control group ( } p<0.001) \text {. } \\
\text { Significance was also found between the } \\
\text { salivary levels of } 8-0 H d G \text { and PPD and } \\
C A L(p<0.001) \text { in the test group. }\end{array}$ & ELISA & $\begin{array}{l}\text { The chronic periodontitis group } \\
\text { required at least four teeth with } \\
\text { a } P P D \geq 5 \mathrm{~mm} \text {, with } C A L \geq 2 \mathrm{~mm} \\
\text { ( } n=20) \text {. The healthy group had } \\
\text { a mean } \mathrm{Gl}<1 \text { and no sites of } \\
\text { attachment loss }(n=20) \text {. }\end{array}$ & 85 \\
\hline Porphyromonas gingivalis & Bacteria & $\begin{array}{l}\text { The optimal copy-counts per } \mathrm{mL} \text { of saliva } \\
\text { for identifity periodontitis by P. gingivalis } \\
\text { was }>40,000 \text {. (AUC: } 0.933 \text {; sensitivity: } \\
0.8919 \text {; specificity: } 0.9459 \text { ). }\end{array}$ & $\begin{array}{l}\text { TaqMan real-time } \\
\text { PCR }\end{array}$ & \multirow{3}{*}{$\begin{array}{l}\text { Periodontally healthy subjects } \\
\text { had no PPD }>3 \mathrm{~mm} \text { and no teeth } \\
\text { with probing attachment loss or } \\
\text { BOP ( } \mathrm{n}=37 \text { ). Gingivitis patients } \\
\text { showed several teeth with BOP } \\
\text { but did not exhibit teeth with } \\
\text { pocket depths }>3 \mathrm{~mm} \text { and had no } \\
\text { teeth with probing attachment } \\
\text { loss ( } \mathrm{n}=31 \text { ). Chronic periodontitis } \\
\text { patients had at least nine posterior } \\
\text { teeth with } 5-7 \mathrm{~mm} \text { pocket depth } \\
\text { and three teeth with } 6 \text { mm or more } \\
\text { of probing attachment loss ( } 46 \text { ). } \\
\text { Aggressive periodontitis patients } \\
\text { exhibited probing attachment } \\
\text { loss }<5 \mathrm{~mm} \text { on more than } 14 \text { teeth, } \\
\text { with at least three teeth other than } \\
\text { incisors or first molars ( } \mathrm{n}=36 \text { ). }\end{array}$} & \multirow[t]{3}{*}{87} \\
\hline Tannerella forsythia & Bacteria & $\begin{array}{l}\text { The optimal copy-counts per } \mathrm{mL} \text { of saliva } \\
\text { for identifity periodontitis by T. forsythia } \\
\text { was }>700,000 \text {. (AUC: } 0.907 \text {; sensitivity: } \\
0.8919 \text {; specificity: } 0.8649 \text { ). }\end{array}$ & $\begin{array}{l}\text { TaqMan real-time } \\
\text { PCR }\end{array}$ & & \\
\hline Prevotella intermedia & Bacteria & $\begin{array}{l}\text { The optimal copy-counts per } \mathrm{mL} \text { of saliva } \\
\text { for identifity periodontitis by P. intermedia } \\
\text { was }>910,000 \text {. (AUC: } 0.874 \text {; sensitivity: } \\
0.8949 \text {; specificity: } 0.8378 \text { ). }\end{array}$ & $\begin{array}{l}\text { TaqMan real-time } \\
\text { PCR }\end{array}$ & & \\
\hline
\end{tabular}

risks and developing personalised treatment options for the best targeted care. ${ }^{93,94}$ It has been shown that the presence of multiple pathogenic periodontal bacterial species is more closely associated with periodontitis than the presence of any one species. ${ }^{89}$ The second, MyPerioID ${ }^{\circledR}$, determines a patient's genetic susceptibility to periodontal disease because of their increased production of the inflammatory cytokines interleukin- $1 \alpha$ and $\beta$ (IL-1 $\alpha$ and IL-1 $\beta$ ) during an inflammatory response. ${ }^{42,95-97}$ This test is scientifically based on genetic polymorphisms of these two genes that increase the production of interleukin-1, a known regulator of the inflammatory response. ${ }^{12,98}$ Both tests were developed by OralDNA ${ }^{\circledR}$ Labs and are currently available through dental care practitioners who are given detailed result reports that can be used to supplement traditional assessments and shared with the patient to inform them of their oral health. However, a shortcoming of these diagnostic tests is that four to five days are needed for results to be delivered. Also, they are able to identify risk factors for periodontitis, but they lack the ability to determine disease activity and provide a projected timeline for when periodontal attachment loss and bone resorption will occur. ${ }^{95}$

\section{POINT-OF-CARE DEVICES FOR SALIVARY DIAGNOSTICS}

The goal of salivary diagnostics is to be able to provide information regarding a number of oral and systemic disease status results to clinicians and patients during the time of a regular check-up. A main hindrance has been that many biomarkers are available in very low quantities in saliva, therefore making detection sensitivity a challenge. However, there are currently different groups working on point-of-care (POC) devices that will allow quick and accurate results using increasingly sensitive detection mechanisms. ${ }^{99}$ A group at the University of Texas at Austin has applied an electronic microchip-assay to detect C-reactive protein (CRP), a biomarker for inflammation associated with periodontal disease at the picogram per milliliter level. ${ }^{100}$ CRP is a systemic marker produced as a response to inflammatory stimuli ${ }^{101,102}$ that can differentiate between healthy and periodontitis in serum ${ }^{103-106}$ and saliva. ${ }^{44,107}$ As CRP is available in lower concentrations in saliva compared to serum, the increased sensitivity of the microchip made it a reality to distinguish between healthy periodontium and chronic gingival inflammation based directly on salivary CRP levels. ${ }^{44,100}$ However, CRP is a systemic marker of inflammation that has been shown to significantly increase 


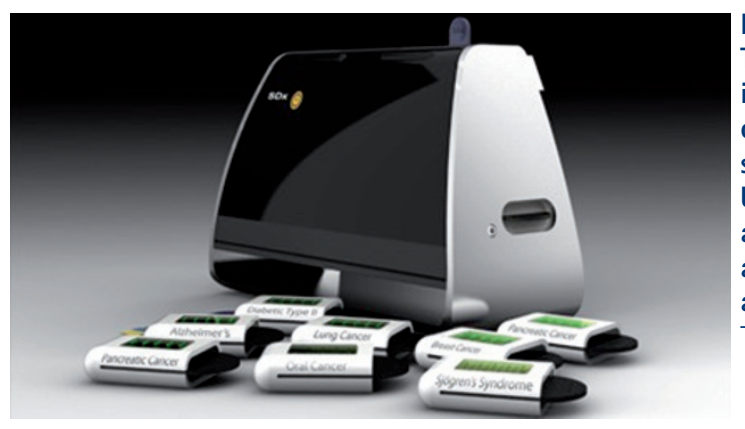

Fig 1 The Oral Fluid NanoSensor Test (OFNASET) technology platform is a point-of-care technology optimized for ultra-sensitive and specific detection of salivary biomarkers for disease detection. In addition it is multiplexible (proteins and nucleic acids RNA/DNA), robust and inexpensive.

for other conditions, including myocardial infarction, atherosclerosis and arthritis. ${ }^{108-110}$ Researchers at Sandia National Laboratories and the University of Michigan, Ann Arbor have also established a POC device that is able to perform immunological assays in under ten minutes with low sample volume and concentration requirements to test for periodontal disease. This device iscalled the integrated microfluidic platform for oral diagnostics (IMPOD). ${ }^{99}$ The IMPOD is able to detect proteins in the picoMolar range for necrosis factor- $\alpha$ (TNF- $\alpha$ ) and interleukin- 6 (IL6) that has been spiked-in to saliva. TNF$\alpha$, a proinflammatory and immune regulatory cytokine, has been identified in saliva and is significantly elevated in people with periodontitis compared with healthy individuals, with increased levels being correlated with increased number of sites with bleeding upon probing, pocket depth, and higher clinical attachment levels. ${ }^{111-114}$ IL-6, which is released in response to IL-1 and TNF, has been shown to increase proportionally with bone loss in adult chronic periodontitis patients. ${ }^{115,116}$ Finally, researchers working at UCLA School of Dentistry are working on discovering and validating biomarkers for periodontal disease in saliva. The biomarkers will then be detected by the Oral Fluid NanoSensor Test (OFNASET) that is able to detect multiplex protein and transcriptomic biomarkers simultaneously. The team at UCLA have developed a OFNASET that provides low cost, real time, highly sensitive and specific POC technology optimized to saliva for clinical applications (Fig. 1). ${ }^{117}$

\section{IMPLICATIONS FOR DENTAL CARE PRACTITIONERS}

As patients with periodontal disease come from a wide range of socioeconomic backgrounds, disparities in accessibility to professional treatment are present. ${ }^{118}$ Even for those with the ability to afford treatment, it is not confirmed that the minor clinical attachment gain justifies the higher cost and extended recovery time of surgical interventions. ${ }^{29,119,120}$ POC periodontal disease testing, whether used in a dental office, health clinic, or purchased directly by the consumer to be used at home would allow healthcare providers to more closely monitor disease progression and allow more time for them to advise their patients of periodontal self-care before the disease becomes irreversible. ${ }^{121}$ Utilising Using a non-invasive, real-time diagnostic tool would allow quicker diagnostic capabilities for practitioners and increased access to dental care in efforts to reduce disparities. ${ }^{95}$

\section{FUTURE DIRECTIONS}

A most important translational goal for salivary biomarkers to achieve clinical reality is the ability to definitively and pivotally validate salivary biomarkers at the regulatory level (Food and Drug Administration). The opportunity to utilise saliva as a diagnostic alternative to blood and urine has been a long sought-out goal that is just recently moving into chairside availability due to advances in robust scientific platform and biomarker validations. However, the potential to utilise saliva for diagnostic screenings for oral and systemic diseases simultaneously remains unfulfiled. It would be ideal to be able to assay a single saliva sample for a wide range of diseases using genomic, proteomic, and bacterial markers. Currently, many salivary biomarkers can test for a number of different diseases, but for saliva to live up to clinical expectations the technology should be able to detect many different biomarkers from a range of diseases simultaneously. ${ }^{122}$ Numerous research groups are working toward this goal by combining microbial markers from periodontal pathogens with salivary biomarkers from host-response changes to those pathogens to further expand the clinical viability of salivary diagnosthe periodontium, it is an advantageous diagnostic fluid for periodontal disease because the analytes reflect the current disease activity that will allow dentists to appropriately determine the severity and guide treatment options. ${ }^{95}$ Various diagnostic tests are commercially available, and the development of point-of-care tests is expanding. Salivary diagnostics for periodontal disease is promising and could facilitate the diagnostics and treatment in a clinical practice by dental practitioners in a near future. tics. ${ }^{42,91}$ As saliva is in constant contact with
Supported by research grant to D. T. W. Wong: NIH grants UH2 TR000923, UO1 DE017593, RO1 DE017170, U01 DE016275, R21 CA0126733 and TRDRP grants 20PTO032 and 21 RTO112 and DoD LC110207, and Fanconi Anaemia Research Fund, Barnes Fund for Head \& Neck Cancer Research and the O'Keefe Foundation.

\section{Disclosures}

David Wong is co-founder of RNAmeTRIX Inc., a molecular diagnostic company. He holds equity in RNAmeTRIX, and serves as a company Director and Scientific Advisor. The University of California also holds equity in RNAmeTRIX. Intellectual property that David Wong invented and which was patented by the University of California has been licenced to RNAmeTRIX.

1. Page R C, Offenbacher S, Schroeder H E, Seymour $\mathrm{G} J$, Kornman K S. Advances in the pathogenesis of periodontitis: summary of developments, clinical implications and future directions. Periodontol 2000 1997: 14: 216-248.

2. Williams R C. Periodontal disease. N Engl J Med 1990; 322: 373-382.

3. Armitage G C. Periodontal diagnoses and classification of periodontal diseases. Periodontol 2000 2004; 34: 9-21.

4. Offenbacher S, Barros S P, Singer R E et al. Periodontal disease at the biofilm-gingival interface. J Periodonto/ 2007; 78: 1911-1925.

5. Hajishengallis G, Liang S, Payne M A et al. Low-abundance biofilm species orchestrates inflammatory periodontal disease through the commensal microbiota and complement. Cell Host Microbe 2011; 10: 497-506.

6. Shaddox L M, Walker C B. Treating chronic periodontitis: current status, challenges, and future directions. Clin Cosmet Investig Dent 2010; 2: 79-91.

7. Haffajee A D, Socransky S S. Microbial etiological agents of destructive periodontal diseases. Periodontol 2000 1994; 5: 78-111.

8. Genco R J, Borgnakke W S. Risk factors for periodontal disease. Periodontol 2000 2013; 62: 59-94.

9. Pihlstrom B. L, Michalowicz B S, Johnson N W. Periodontal diseases. Lancet 2005; 366: 1809-1820.

10. Pihlstrom B L. Periodontal risk assessment, diagnosis and treatment planning. Periodontol 2000 2001; 25: 37-58.

11. Bergström J, Preber $\mathrm{H}$. Tobacco use as a risk factor. J Periodontol 1994; 65: 545-550.

12. Kornman K S, Crane A, Wang H Y et al. The interleukin 1 genotype as a severity factor in adult periodontal disease. J Clin Periodontol 1997; 24: 72-77.

13. Hart T C, Kornman K S. Genetic factors in the pathogenesis of periodontitis. Periodontol 2000 1997; 14: 202-215.

14. Grossi S G, Genco R J. Periodontal disease and diabetes mellitus: a two-way relationship. Ann Periodontol 1998; 3: 51-61.

15. Burt B, Research, Science and Therapy Committee of the American Academy of Periodontology. Position paper: epidemiology of periodontal diseases. J Periodontol 2005; 76: 1406-1419.

16. Löe H, Silness J. Periodontal disease in pregnancy. I. Prevalence and severity. Acta Odontol Scand 1963; 21: 533-551

17. Silness J, Loe H. Periodontal disease in pregnancy. II. Correlation between oral hygiene and periodontal condition. Acta Odontol Scand 1964; 22: 121-135.

18. Socransky S S, Haffajee A D, Cugini M A, Smith C, Kent R L, Jr. Microbial complexes in subgingiva plaque. J Clin Periodontol 1998; 25: 134-144.

19. Albandar J M, Kingman A. Gingival recession, gingival bleeding, and dental calculus in adults 30 years of age and older in the United States, 1988-1994. J Periodonto/ 1999; 70: 30-43.

20. Brown L J, Oliver R C, Loe H. Periodontal diseases in the US. in 1981: prevalence, severity, extent, and role in tooth mortality. J Periodontol 1989; 60: 363-370.

21. Morris A J, Steele J, White D A. The oral cleanliness 
and periodontal health of UK adults in 1998. Br Dent J 2001; 191: 186-192.

22. Eke PI, Dye B A, Wei L et al. Prevalence of periodontitis in adults in the United States: 2009 and 2010. J Dent Res 2012; 91: 914-920.

23. Axelsson $P$, Lindhe J. Effect of controlled oral hygiene procedures on caries and periodontal disease in adults. Results after 6 years. $J$ Clin Periodontol 1981; 8: 239-248.

24. Axelsson $\mathrm{P}$, Lindhe J. The significance of maintenance care in the treatment of periodontal disease. J Clin Periodontol 1981; 8: 281-294.

25. Axelsson $P$, Nyström $B$, Lindhe J. The long-term effect of a plaque control programme on tooth mortality, caries and periodontal disease in adults. Results after 30 years of maintenance. J Clin Periodontol 2004; 31: 749-757.

26. Tunkel J, Heinecke A, Flemmig T F. A systematic review of efficacy of machine-driven and manual subgingival debridement in the treatment of chronic periodontitis. J Clin Periodontol 2002; 29 (Suppl 3): 72-81; discussion 90-91.

27. Edwardsson S, Bing M, Axtelius B et al. The microbiota of periodontal pockets with different depths in therapy-resistant periodontitis. J Clin Periodontol 1999; 26: 143-152.

28. Van der Weijden G A, Timmerman M F. A systematic review on the clinical efficacy of subgingival debridement in the treatment of chronic periodontitis. J Clin Periodontol 2002; 29 (Suppl 3) 55-71: discussion 90-91.

29. Heitz-Mayfield L J, Lang N P. Surgical and nonsurgical periodontal therapy. learned and unlearned concepts. Periodontol 2000 2013; 62: 218-231.

30. Cortellini P, Tonetti M S. Clinical and radiographic outcomes of the modified minimally invasive surgical technique with and without regenerative materials: a randomized-controlled trial in intrabony defects. J Clin Periodonto/ 2011; 38: 365-373.

31. Ramseier C A, Rasperini G, Batia S, Giannobile W V. Advanced reconstructive technologies for periodontal tissue repair. Periodontol 2000 2012; 59: 185-202

32. Slate $E H$, Bandyopadhyay $D$. An investigation of the MCSIMEX method with application to measurement error in periodontal outcomes. Stat Med 2009; 28: 3523-3538.

33. van der Velden U. Purpose and problems of periodontal disease classification. Periodontol 2000 2005; 39: 13-21.

34. Armitage G C. Development of a classification system for periodontal diseases and conditions. Ann Periodontol 1999; 4: 1-6.

35. Mittal V, Bhullar R P, Bansal R et al. A practicable approach for periodontal classification. Dent Res J (Isfahan) 2013; 10: 697-703.

36. Zhang L, Henson B S, Camargo P M, Wong D T. The clinical value of salivary biomarkers for periodonta disease. Periodontol 2000 2009; 51: 25-37.

37. Armitage G C, Research, Science and Therapy Committee of the American Academy of Periodontology. Diagnosis of periodontal diseases. J Periodontol 2003; 74: 1237-1247.

38. Ai J Y, Smith B, Wong D T. Bioinformatics advances in saliva diagnostics. Int J Oral Sci 2012; 4: 85-87.

39. Zimmermann B G, Park N J, Wong D T. Genomic targets in saliva. Ann N Y Acad Sci 2007; 1098: 184-191.

40. Hu S, Xie Y, Ramachandran P et al. Largescale identification of proteins in human salivary proteome by liquid chromatography/ mass spectrometry and two-dimensional gel electrophoresis-mass spectrometry. Proteomics 2005; 5: 1714-1728.

41. Ghafouri B, Tagesson C, Lindahl M. Mapping of proteins in human saliva using two-dimensiona gel electrophoresis and peptide mass fingerprinting. Proteomics 2003; 3: 1003-1015.

42. Giannobile W V. Salivary diagnostics for periodontal diseases. J Am Dent Assoc 2012; 143 (10 Suppl): 6S-11S.

43. Eng G, Chen A, Vess T, Ginsburg G S. Genome technologies and personalized dental medicine. Oral Dis 2012; 18: 223-235.

44. Christodoulides N, Floriano P N, Miller C S et al. Labona-chip methods for pointofcare measurements of salivary biomarkers of periodontitis. Ann NY Acad Sci 2007; 1098: 411-428

45. Giannobile W V, Beikler T, Kinney J S et al. Saliva as a diagnostic tool for periodontal disease: current state and future directions. Periodontol 2000 2009; 50: 52-64.

46. Hu S, Wong D T. Oral cancer proteomics. Curr Opin Mol Ther 2007; 9: 467-476.

47. Hu S, Gao K, Pollard R et al. Preclinical validation of salivary biomarkers for primary Sjögren's syndrome. Arthritis Care Res (Hoboken) 2010; 62: 1633-1638.

48. Zhang $\mathrm{L}$, Xiao $\mathrm{H}$, Karlan S et al. Discovery and preclinical validation of salivary transcriptomic and proteomic biomarkers for the non-invasive detection of breast cancer. PLoS One 2010; 5: e15573.

49. Zhang L, Farrell J J, Zhou H et al. Salivary transcriptomic biomarkers for detection of resectable pancreatic cancer. Gastroenterology 2010; 138: 949-957.

50. Mortimer P P, Parry J V. Detection of antibody to HIV in saliva: a brief review. Clin Diagn Virol 1994; 2 : 231-243.

51. Hodinka R L, Nagashunmugam T, Malamud D. Detection of human immunodeficiency virus antibodies in oral fluids. Clin Diagn Lab Immunol 1998; 5: 419-426.

52. Kaufman E, Lamster I B. The diagnostic applications of saliva - a review. Crit. Rev. Oral Biol. Med. 2002; 13: 197-212.

53. Miller C S, Foley J D, Bailey A L et al. Current developments in salivary diagnostics. Biomark Med 2010; 4: 171-189.

54. Sueda T, Bang J, Cimasoni G. Collection of gingival fluid for quantitative analysis. J Dent Res 1969; 48: 159.

55. Kinney J S, Morelli T, Oh M et al. Crevicular fluid biomarkers and periodontal disease progression. J Clin Periodontol 2014; 41: 113-120.

56. Leppilahti J, Hernández-Ríos P, Gamonal J et al. MMPs and myeloperoxidase in GCF provide sitespecific diagnostic value for chronic periodontitis. J Clin Periodontol 2014; 41: 348-356.

57. Griffiths G S, Wilton J M, Curtis M A. Contamination of human gingival crevicular fluid by plaque and saliva. Arch Oral Biol 1992; 37: 559-564.

58. Perinetti G, Di Leonardo B, Di Lenarda R, Contardo L. Repeatability of gingival crevicular fluid collection and quantification, as determined through its alkaline phosphatase activity: implications for diagnostic use. J Periodontal Res 2013; 48: 98-104.

59. Kaufman E, Lamster I B. Analysis of saliva for periodontal diagnosisa review. J Clin Periodontol 2000; 27: 453-465.

60. Lazarevic V, Whiteson K, Gaïa N et al. Analysis of the salivary microbiome using culture-independent techniques. J Clin Bioinforma 2012; 2: 4

61. Demmer R T, Behle J H, Wolf D L et al. Transcriptomes in healthy and diseased gingival tissues. J Periodontol 2008; 79: 2112-2124.

62. Chen W, Samuelson F W, Gallas B D et al. On the assessment of the added value of new predictive biomarkers. BMC Med Res Methodol 2013; 13: 98.

63. Warnock D G, Peck C C. A roadmap for biomarker qualification. Nature Biotechnology 2010; 28: 444-445.

64. Woessner J F. The family of matrix metalloproteinases. Ann N Y Acad Sci 1994; 732: 11-21.

65. Birkedal-Hansen H. Role of matrix metalloproteinases in human periodontal diseases. J Periodontol 1993; 64: 474-484.

66. Nagase H. Activation mechanisms of matrix metalloproteinases. Biol Chem 1997; 378: 151-160.

67. Kubota $T$, Itagaki M, Hoshino C et al. Altered gene expression levels of matrix metalloproteinases and their inhibitors in periodontitis-affected gingival tissue. J Periodonto/ 2008; 79: 166-173.

68. Visse R, Nagase H. Matrix metalloproteinases and tissue inhibitors of metalloproteinases: structure, function, and biochemistry. Circ Res 2003; 92 : 827-839.

69. Hanemaaijer R, Sorsa T, Konttinen $Y T$ et al. Matrix metalloproteinase8 is expressed in rheumatoid synovial fibroblasts and endothelial cells. Regulation by tumour necrosis factor-alpha and doxycycline.
J Biol Chem 1997; 272: 31504-31509

70. Cole A A, Kuettner K E. MMP-8 (neutrophil collagenase) mRNA and aggrecanase cleavage products are present in normal and osteoarthritic human articular cartilage. Acta Orthop Scand Supp/ 1995; 266: 98-102.

71. Kiili M, Cox S W, Chen H Y et al. Collagenase-2 (MMP-8) and collagenase-3 (MMP-13) in adult periodontitis: molecular forms and levels in gingival crevicular fluid and immunolocalisation in gingival tissue. J Clin Periodontol 2002; 29: 224-232.

72. Gursoy U K, Könönen E, Pradhan-Palikhe P et al. Salivary MMP-8, TIMP-1, and ICTP as markers of advanced periodontitis. J Clin Periodontol 2010; 37: 487-493.

73. Rathnayake N, Akerman S, Klinge B et al. Salivary biomarkers of oral health: a cross-sectional study. J Clin Periodontol 2013; 40: 140-147.

74. Ebersole J L, Schuster J L, Stevens J et al. Patterns of salivary analytes provide diagnostic capacity for distinguishing chronic adult periodontitis from health. J Clin Immunol 2013; 33: 271-279.

75. Uitto V J, Overall C M, McCulloch C. Proteolytic host cell enzymes in gingival crevice fluid. Periodontol 2000 2003; 31: 77-104

76. Isaza-Guzmán D M, Arias-Osorio C, Martínez-Pabón M C, Tobón-Arroyave S I. Salivary levels of matrix metalloproteinase (MMP)9 and tissue inhibitor of matrix metalloproteinase (TIMP) 1: a pilot study about the relationship with periodontal status and MMP-9(-1562C/T) gene promoter polymorphism. Arch Oral Biol 2011; 56: 401-411.

77. Haigh B J, Stewart K W, Whelan J R et al. Alterations in the salivary proteome associated with periodontitis. J Clin Periodontol 2010; 37: 241-247.

78. Kojima T, Andersen E, Sanchez J C et al. Human gingival crevicular fluid contains MRP8 (S100A8) and MRP14 (S100A9), two calcium-binding proteins of the S100 family. J Dent Res 2000; 79: 740-747.

79. Ross K F, Herzberg M C. Calprotectin expression by gingival epithelial cells. Infect Immun 2001; 69: 3248-3254.

80. Calvo F O, Fillet M, de Seny D et al. Biomarker discovery in asthma-related inflammation and remodeling. Proteomics 2009; 9: 2163-2170.

81. Al-Sabbagh M, Alladah A, Lin Y et al. Bone remodeling-associated salivary biomarker MIP1a distinguishes periodontal disease from health. J Periodontal Res 2012; 47: 389-395.

82. Tsai C C, Kao C C, Chen C C. Gingival crevicular fluid lactoferrin levels in adult periodontitis patients. Aust Dent J 1998; 43: 40-44.

83. Glimvall $\mathrm{P}$, Wickström $\mathrm{C}$, Jansson $\mathrm{H}$. Elevated levels of salivary lactoferrin, a marker for chronic periodontitis? J Periodontal Res 2012; 47: 655-660.

84. Shigenaga M K, Gimeno C J, Ames B N. Urinary 8hydroxy2'-deoxyguanosine as a biological marker of in vivo oxidative DNA damage. Proc Natl Acad Sci USA 1989; 86: 9697-9701.

85. Suzuki S, Shishido T, Ishino M et al. 8Hydroxy2'deoxyguanosine is a prognostic mediator for cardiac event. Eur J Clin Invest 2011; 41: 759-766.

86. Avouac J, Borderie D, Ekindjian O G, Kahan A Allanore $Y$. High DNA oxidative damage in systemic sclerosis. J Rheumatol 2010; 37: 2540-2547.

87. Sawamoto Y, Sugano N, Tanaka H, Ito K. Detection of periodontopathic bacteria and an oxidative stress marker in saliva from periodontitis patients. Oral Microbiol Immunol 2005; 20: 216-220.

88. Sezer U, Ciçek Y, Canakçi C F. Increased salivary levels of 8-hydroxydeoxyguanosine may be a marker for disease activity for periodontitis. Dis Markers 2012: 32: 165-172.

89. Paju S, Pussinen PJ, Suominen-Taipale L et al. Detection of multiple pathogenic species in saliva is associated with periodontal infection in adults. J Clin Microbio/ 2009: 47: 235-238.

90. Saygun I, Nizam N, Keskiner I et al. Salivary infectious agents and periodontal disease status. J Periodontal Res 2011; 46: 235-239.

91. Kinney J S, Morelli T, Braun T et al. Saliva/pathogen biomarker signatures and periodontal disease progression. J Dent Res 2011; 90: 752-758.

92. Nabors T W, McGlennen R C, Thompson D. Salivary testing for periodontal disease diagnosis and treatment. Dent Today 2010; 29: 53-54-56, 58-60; 
quiz 61.

93. Salminen A, Gursoy U K, Paju S et al. Salivary biomarkers of bacterial burden, inflammatory response, and tissue destruction in periodontitis. J Clin Periodontol 2014; 41: 442-450.

94. Sakamoto M, Takeuchi Y, Umeda M, Ishikawa I, Benno Y. Rapid detection and quantification of five periodontopathic bacteria by real-time PCR. Microbiol Immunol 2001; 45: 39-44.

95. Kim J J, Kim C J, Camargo P M. Salivary biomarkers in the diagnosis of periodontal diseases. J Calif Dent Assoc 2013; 41: 119-124.

96. McGuire M K, Nunn M E. Prognosis versus actua outcome. IV. The effectiveness of clinical parameters and IL1 genotype in accurately predicting prognoses and tooth survival. J Periodontol 1999; 70: 49-56.

97. Eickholz P, Kaltschmitt J, Berbig J Reitmeir P, Pretzl B. Tooth loss after active periodontal therapy. 1: patient-related factors for risk, prognosis, and quality of outcome. J Clin Periodontol 2008; 35: 165-174.

98. Page $\mathrm{R} C$. The role of inflammatory mediators in the pathogenesis of periodontal disease. J Periodontal Res 1991; 26: 230-242.

99. Herr A E, Hatch A V Giannobile W V et al. Integrated microfluidic platform for oral diagnostics. Ann NY Acad Sci 2007; 1098: 362-374.

100. Christodoulides N, Mohanty S, Miller C S et al. Application of microchip assay system for the measurement of Creactive protein in human saliva. Lab Chip 2005; 5: 261-269.

101. Sabel K G, Hanson L A. The clinical usefulness of Creactive protein (CRP) determinations in bacterial meningitis and septicaemia in infancy. Acta Paediatr Scand 1974; 63: 381-388.

102. Pasceri V, Willerson J T, Yeh E T H. Direct proinflammatory effect of Creactive protein on human endothelial cells. Circulation 2000; 102: 2165-2168.

103. Wu T, Trevisan M, Genco R J et al. Examination of the relation between periodontal health status and cardiovascular risk factors: serum total and high density lipoprotein cholesterol, C-reactive protein, and plasma fibrinogen. Am J Epidemiol 2000; 151: 273-282.

104. Joshipura K J, Wand H C, Merchant A T, Rimm E B. Periodontal disease and biomarkers related to cardiovascular disease. J Dent Res 2004; 83 : 151-155.

105. Loos B G, Craandijk J, Hoek F J, Wertheim-van Dillen $P M$, van der Velden U. Elevation of systemic markers related to cardiovascular diseases in the peripheral blood of periodontitis patients. J Periodontol 2000; 71: 1528-1534.

106. Slade G D, Offenbacher S, Beck J D, Heiss G, Pankow J S. Acute-phase inflammatory response to periodontal disease in the US population. J Dent Res 2000; 79: 49-57.

107. Paederson E D, Stanke S R, Whitener S J et al. Salivary levels of alpha 2 macroglobulin, alpha 1antitrypsin, Creactive protein, cathepsin $\mathrm{G}$ and elastase in humans with or without destructive periodontal disease. Arch Oral Biol 1995; 40: $1151-1155$.

108. Milovanovic M, Nilsson $E_{1}$ Järemo P. Relationships between platelets and inflammatory markers in rheumatoid arthritis. Clin Chim Acta 2004; 343: 237-240.

109. Ridker P M, Glynn R J, Hennekens C H. CReactive protein adds to the predictive value of total and HDL cholesterol in determining risk of first myocardial infarction. Circulation 1998; 97: 2007-2011.

110. Ridker P M, Stampfer M J, Rifai N. Novel risk factors for systemic atherosclerosis: a comparison of Creactive protein, fibrinogen, homocysteine, lipoprotein(a), and standard cholesterol screening as predictors of peripheral arterial disease. JAMA 2001; 285: 2481-2485.

111. Bartold P M, Marshall R I, Haynes D R. Periodontitis and rheumatoid arthritis: a review. J Periodontol
2005; 76: 2066-2074

112. Fine D H, Markowitz K, Furgang D et al. Macrophage inflammatory protein-1alpha: a salivary biomarker of bone loss in a longitudinal cohort study of children at risk for aggressive periodontal disease? J Periodonto/ 2009; 80: 106-113.

113. Ng P Y, Donley M, Hausmann E et al. Candidate salivary biomarkers associated with alveolar bone loss: cross-sectional and in vitro studies. FEMS Immunol Med Microbiol 2007; 49: 252-260.

114. Frodge B D, Ebersole J L, Kryscio R J, Thomas M $V$, Miller C S. Bone remodeling biomarkers of periodontal disease in saliva. J Periodontol 2008; 79: 1913-1919.

115. Nakajima K, Matsuda T, Fujitani Y et al. Signal transduction through IL6 receptor: involvement of multiple protein kinases, stat factors, and a novel H7-sensitive pathway. Ann N Y Acad Sci 1995; 762: 55-70.

116. Irwin C R, Myrillas T T. The role of IL6 in the pathogenesis of periodontal disease. Oral Dis 1998; 4: 43-47.

117. Gau V, Wong D. Oral fluid nanosensor test (OFNASET) with advanced electrochemical-based molecular analysis platform. Ann N Y Acad Sci 2007 ; 1098: 401-410.

118. Thomson W M, Sheiham A, Spencer A J. Sociobehavioural aspects of periodontal disease. Periodontol 2000 2012; 60: 54-63.

119. Slots J. Periodontology: past, present, perspectives. Periodontol 2000 2013; 62: 7-19.

120. Seymour R A, Blair G S, Wyatt F A. Post-operative dental pain and analgesic efficacy. Part I. Br J Oral Surg 1983; 21: 290-297.

121. van der Weijden F, Slot D E. Oral hygiene in the prevention of periodontal diseases: the evidence. Periodontol 2000 2011; 55: 104-123.

122. Liu J, Duan Y Saliva: a potential media for disease diagnostics and monitoring. Oral Oncol 2012; 48: 569-577. 